\title{
Structural master plan of flood mitigation measures
}

\author{
A. Heidari \\ Iran Water and Power resources development Co. (IWPC), Tehran, Iran
}

Received: 21 July 2008 - Revised: 6 October 2008 - Accepted: 5 November 2008 - Published: 20 January 2009

\begin{abstract}
Flood protection is one of the practical methods in damage reduction. Although it not possible to be completely protected from flood disaster but major part of damages can be reduced by mitigation plans. In this paper, the optimum flood mitigation master plan is determined by economic evaluation in trading off between the construction costs and expected value of damage reduction as the benefits. Size of the certain mitigation alternative is also be obtained by risk analysis by accepting possibility of flood overtopping. Different flood mitigation alternatives are investigated from various aspects in the Dez and Karun river floodplain areas as a case study in south west of IRAN. The results show that detention dam and flood diversion are the best alternatives of flood mitigation methods as well as enforcing the flood control purpose of upstream multipurpose reservoirs. Dyke and levees are not mostly justifiable because of negative impact on down stream by enhancing routed flood peak discharge magnitude and flood damages as well.
\end{abstract}

\section{Introduction}

Structural river training plans are traditionally known methods of flood mitigation and this method has been used in corporation with general flood management approach in most of flood pain areas. Although the non-structural approaches have recently been come up as an effective method of risk management but without developing structural measures, they would be less effective. Flood risk reduction can access by reducing the magnitude of flood or vulnerability of effected area. Flood damages determination is not only important factor for risk management but also it is a significant parameter in evaluation of mitigation plan according to the type and size of measures. However in the design stage, quantification of flood damages reduction is inevitable for

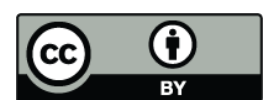

Correspondence to: A. Heidari (al.heidari@iwpco.com) different alternatives e.g. river training methods or size of protection measures. The damage analysis determines the best alternative of protection as well as the optimum size of the structure.

Quantification of risk costs is one of the important parts of the analysis. Risk costs are those cost items incurred due to the breach of the structures and can be categorized into tangible and intangible costs. Tangible costs include damage to properties and structures, loss in business, cost of repair, etc. On the other hand, intangible costs are not measurable by monetary unit such as psychological trauma, loss of lives, social unrest, damage to environment, and others. However, these costs should be taken to account in the analysis by general judgment depend on vulnerability of area. It is not possible to quantify the benefits of the project without considering risk costs. This concept is the common part of the various flood mitigation systems such as storm sewer systems (Yen and Jun, 1984), levees (Tung and Mays, 1981), dams and spillways (Tang and Yen, 1993), and storm surge protection work (Vrijling, 1993).

Tung (2002) demonstrated a risk-based design of flood defense system. Van Stokkom and Smit (2002) have investigated different flood mitigation scenarios considering climate change and vulnerability of floodplain area in Netherlands. Cheng et al. (1993) demonstrated how to apply the reliability analysis method to calculate the risk reduction associated with freeboard in dam design. However, it is the risk-based design of hydraulic structures that has the most potential for significant application of reliability analysis.

A flood mitigation plan should include one or more practical measures to reduce the flood damage. The structural and non structural methods of flood mitigation have been categorized as Table 1 (HEC, 1998).

A flood mitigation plan should cover the following issues:

- The best implementation method to control the flood;

- the most appropriate location to install the facilities;

- the most suitable size for the facilities;

Published by Copernicus Publications on behalf of the European Geosciences Union. 
Table 1. Flood damage-reduction measures.

\begin{tabular}{llll}
\hline $\begin{array}{l}\text { Measures } \\
\text { that reduce } \\
\text { damage by } \\
\text { reducing } \\
\text { discharge }\end{array}$ & $\begin{array}{l}\text { Measures that } \\
\text { reduce damage } \\
\text { by reducing } \\
\text { stage }\end{array}$ & $\begin{array}{l}\text { Measures that } \\
\text { reduce damage } \\
\text { by reducing } \\
\text { existing damage } \\
\text { susceptibility }\end{array}$ & $\begin{array}{l}\text { Measures that } \\
\text { reduce damage } \\
\text { by reducing } \\
\text { future damage } \\
\text { susceptibility }\end{array}$ \\
\hline Reservoir & $\begin{array}{l}\text { Channel } \\
\text { improvement }\end{array}$ & Levee or floodwall & $\begin{array}{l}\text { Land-use and } \\
\text { construction } \\
\text { regulation }\end{array}$ \\
$\begin{array}{l}\text { Diversion } \\
\begin{array}{l}\text { Watershed } \\
\text { management }\end{array}\end{array}$ & Flood proofing & $\begin{array}{l}\text { Acquisition } \\
\text { Relocation } \\
\text { Flood warning and } \\
\text { preparedness } \\
\text { planning }\end{array}$ & \\
& & &
\end{tabular}

- the best method for operation and maintenance of the facilities.

In order to determine the optimum alternative for mitigation, the location, the size of the structures and operation condition of different alternatives should be presented. Then the alternatives will be evaluated individually by an economical criterion of flood damage-reduction and investment cost. The objective is mainly to identify a mitigation plan that meets three key criteria:

- Positive net benefit;

- observing environmental standards;

- acceptable for local interest.

This is achieved through performing "River training" plans and then flood damage analysis for existing or "without project" condition. In this method, damage-reduction amount in case of implementation of the mitigation plan considered as benefit of the plan. Economic evaluation of the alternatives reveals the convenient alternative after designing different components of proposed mitigation plan. This paper shows structural flood mitigation plans investigation results for Dez and Karun river floodplain areas.

\section{Risk based analysis of mitigation plans}

This study includes flood damage risk-based analysis by determination of flood damage rate for different flood levels in existing situation (without project) and with considering different alternatives of flood mitigation plans. The effort aims to provide details of the approach and methodology for the following key components:

- Review of historical data for flood magnitudes and frequency analysis;

- upper storage reservoir flood control simulation;
- collection of historical data for flood damages;

- flood damage field survey;

- hydrodynamic river modeling;

- analysis of flood mitigation options;

- model simulation aimed at predicting flood levels and determining the protection standards needed;

- flood damage risk-based analysis and cost-benefit economic analysis.

The flood mitigation study will identify the most critical areas of flooding, and determine the best alternative for flood damage reduction. The study focuses on the areas where damages and losses are greatest and proposes accordingly a preliminary master plan for the region. The process includes damage cost assessment for different flood levels in various plans separately. It is therefore necessary to carry out a cost/benefit analysis for the main mitigation schemes and select the best alternative by means of flood damage riskbased analysis and cost assessment.

Flood frequency analysis is required to identify the flood magnitude for each return period. Therefore a comprehensive flood frequency analysis has been carried out for the upper and intermediate catchments. Reservoir flood control simulation determines flood attenuation by upper storage reservoirs and provides the flood hydrograph for the downstream area for different return periods. The critical situation is assumed regarding to initial condition of reservoirs and flood hydrographs combination of the catchments. Therefore the computed hydrograph in upstream of floodplain area is the maximum possible flood based on the river system features. In order to determine flood inundation depth in the floodplain areas, hydrodynamic river model is required. In this regard, HEC-RAS model was used with available data of the Dez and Karun rivers. The model was developed to predict discharges and water levels of each reach for different return periods of floods in existing situation and mitigation plan alternatives.

Flood damage estimation in inundated areas is one of the key parts of the flood studies. In order to provide an accurate damage amount, a flood damage survey was carried out in the most critical areas of the flood plains in addition to gathering historical data of damage from recent floods. Historical flood damage data was not reliable due to lack of insurance support in the area and main sources of these data was newspapers and general evaluation of natural disaster office. Therefore estimating of potential damage based on the vulnerability of the region was the only reliable method in the damage analysis. In the flood survey, potential flood damage areas were identified and a set of questionnaires were designed and filled out for residential, agricultural and industrial properties. A GIS database was built using maps and the results from the survey. 
HEC-FDA (1998) software was used in this study for the following purposes:

- Determination of expected benefits of the proposed flood mitigation plans with regards to expected damagereduction by implementing the plan in comparison with not implementing the plan condition.

- Description of the uncertainty of computing probability-discharge, discharge-stage and stagedamage and determining the effects in reducing the damages by Monte Carlo method. A variable limit and uniform distribution was defined for the mentioned parameters based on the variability of models parameters or probabilistic manner of the results. For instance, 95\% confidence limit was considered for flood frequency curves and limit of water level was determined based on the possible variation range of manning " $n$ " coefficient. The ultimate results of analysis were sensitive to magnitude of parameter rather then the variation of them because of large scale of case study. Therefore uncertainty and variability of parameter was not taken to account in the procedures.

FDA software was used in the benefit analysis for various mitigation alternatives. A risk-based damage analysis was carried out to identify annual benefits of a certain mitigation alternative and economic assessment was performed based on cost - benefit analysis in order to select the best alternatives.

A flood mitigation plan can decrease damages by reducing discharge, stage or damage susceptibility. Net benefit of these plans can be calculated by costs/benefits analysis of project in optimum design flood. Optimum return period of design flood can be determined by trade off between construction costs and operational benefits in certain plan considering risk of failure of the structure. However the optimum retune period was considered 25 year for river training measures such as dykes and diversion based on the guidelines and the flood mitigation alternatives were designed for this flood peak discharge after routing along the rivers. Detention dam height was determined based on maximum feasible height regardless of flood magnitudes.

The damage-reduction benefit can be computed by subtracting damages in without and with project condition. The random nature of flood causes to use "Expected Value" for computing the benefit of damage reduction. Therefore, net benefit of the plan can be expressed as follow:

$\mathrm{NB}=\left(E\left[X_{\text {without }}\right]-E\left[X_{\text {with }}\right]\right)-C$

Where $E[$ ]=expected value which consider the probability of flood occurrence. $X_{\text {without }}$ and $X_{\text {with }}$ are damages in without and with project condition respectively. The expected value of inundation damage is computed as follow:

$E[x]=\int_{-\infty}^{+\infty} x f_{x}(x) d x$

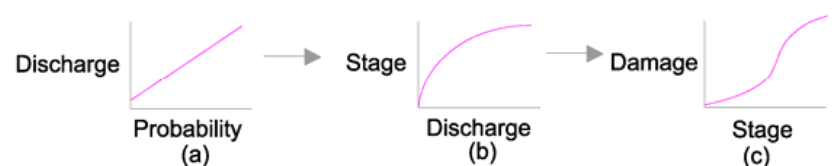

(a)

(c)

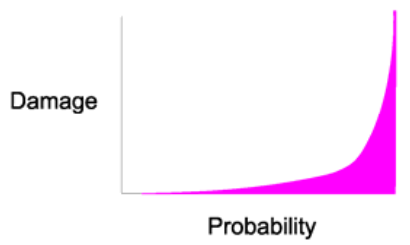

Fig. 1. The process of computing flood expected annual damage.

Where $x=$ random value of damage that occurs with a probability of $f_{x}(x) . f_{x}(x)=$ referred to Probability Density Function (PDF) of $X$. PDF can be converted to the following form of Cumulative Distribution Function (CDF):

$E[x]=\int_{-\infty}^{+\infty} x \frac{d F_{x}(x)}{d x} d x$

The damage-probability function can be obtained by converting hydrological, hydraulic and damage analysis results as Fig. 1.

\section{Results}

\subsection{Case study features}

Karun and Dez basin rivers, which located in the south west of IRAN are the most important rivers of the country. Catchments cover an area of over $60000 \mathrm{~km}^{2}$. The main rivers in the floodplain areas have more than $580 \mathrm{~km}$ long totally and flood inundation is frequently happens in the area. There are 12 dams and hydropower plants under construction and investigation in upper catchments of the basin in addition to 4 dams under operation dams. Catchments location shown in Fig. 2, indicating under operation and construction dams and sub catchments of local flows. Under investigation floodplain area has been located in down stream of the last dams in the both Dez and Karun catchments.

This study concentrates on areas where agricultural and residential losses are significant. In this regard, Ahwaz city is the most critical population center in the vicinity of big Karun river. There are more than $300000 \mathrm{hr}$ irrigation areas along the rivers which were considered in damage estimation of inundated areas. In this paper, structural measures of damage reduction including detention dam, dyke and diversion channel, has been considered for different reaches of river and evaluation of each measure has been carried out based on the impact of the measures on all reaches of rivers. 


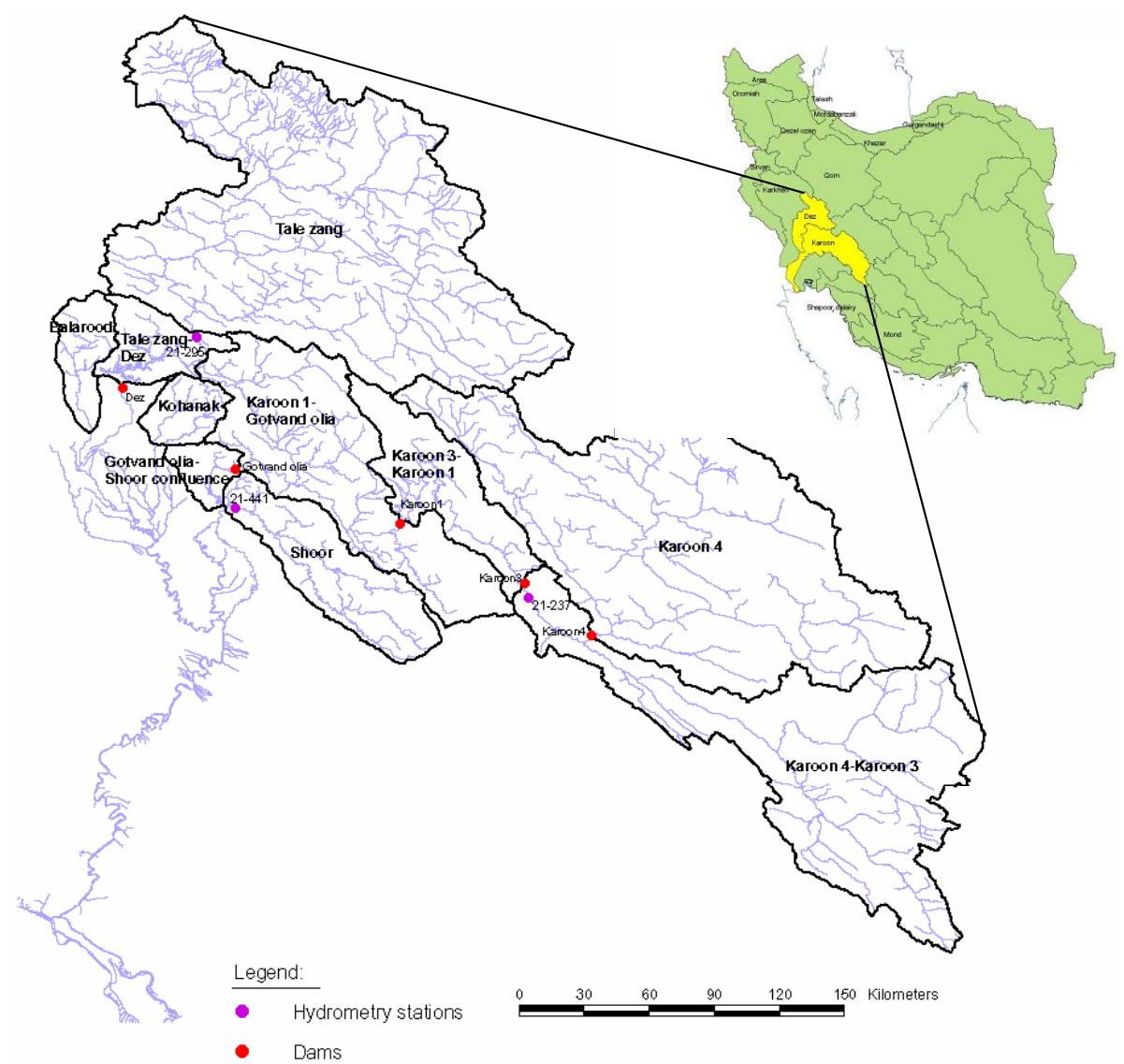

Fig. 2. Dez and Karun catchments and dams location.

\subsection{Flood frequency results}

The flood discharge magnitude is one of the most important parameters in flood mitigation studies. In addition to peak discharges, it is necessary to determine the flood volume because of the impact of reservoirs on flood attenuation. The regional flood analysis method has been applied to determine flood peak discharges after eliminating the heterogeneous station by Dalrymple and Confidence limits tests. The following relationships were obtained for upper catchments of the Karun and Dez basins.

* Karun upper catchments:

$$
Q_{2.33}=413.77+0.82 A^{0.747}-0.0008 H^{1.74}
$$

* Dez upper catchments:

$$
Q_{2.33}=123+0.146 A-0.1123 H
$$

Where $Q_{2.33}, A$ and $H$ are average peak discharge in cms, area in $\mathrm{km}^{2}$ and altitude in $\mathrm{m}$ a.s.l., respectively.
Comparing observed data with fitted relationships shown in Figs. 3 and 4 for the Karun and Dez catchments, respectively. Flood regional relationship for downstream catchments shown in Figs. 5 and 6 for Karun and Dez respectively. Relationship of $Q_{T} / Q_{2.33}$ ratio versus $T$ was determined based on flood frequency analysis in the stations and shown in Figs. 7 and 8 for Karun and Dez catchments respectively.

Flood index method and rainfall - runoff (RR) model were used in order to determine flood hydrograph in upper catchments and intermediate basins. HEC1 and HMS softwares were applied to simulate flood hydrograph after calibrating the model based on observed data. The catchement divided to sub basins and routing reaches as shown in Fig. 9 and calibration was carried out for exponential infiltration parameters, Clark unit hydrograph parameters and snowmelt coefficient in gage station and the results extended to sub basins and intermediate basins. Figure 10 shows the calibration results in different gage stations of the catchments.

Flood index method was based on observed hydrographs in gage station which mostly used for upper catchments. In intermediate catchments, Rainfall frequency analysis results were used in corporation with calibrated RR model. The re- 


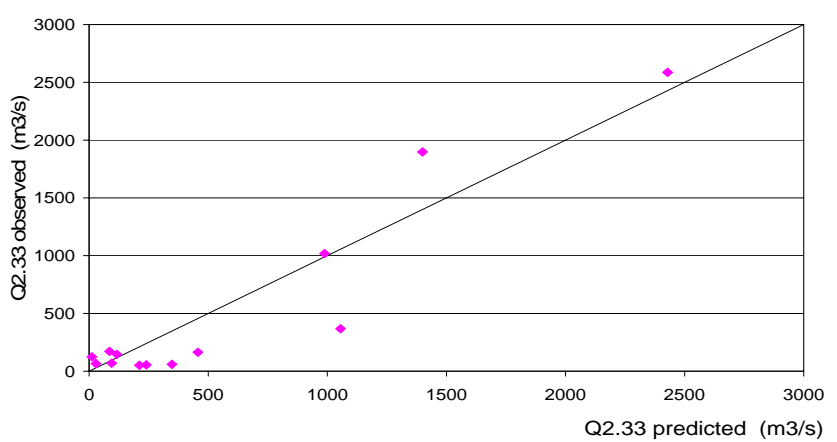

Fig. 3. Comparison of observed and predicted values of average peak discharge in Karun catchment.

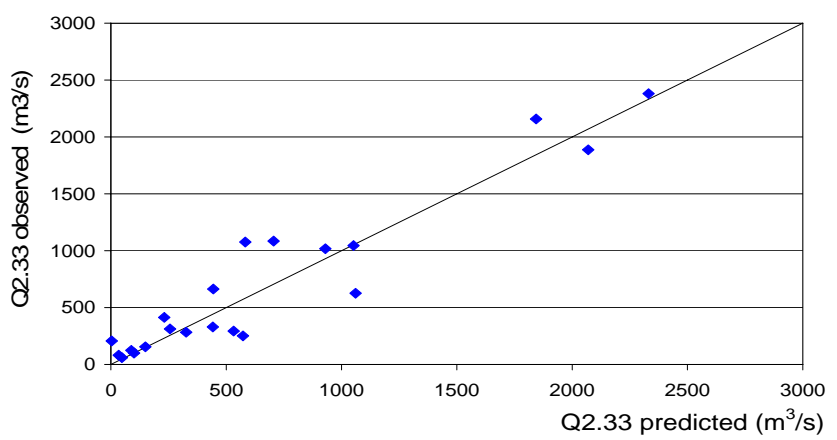

Fig. 4. Comparison of observed and predicted values of average peak discharge in Dez catchment.

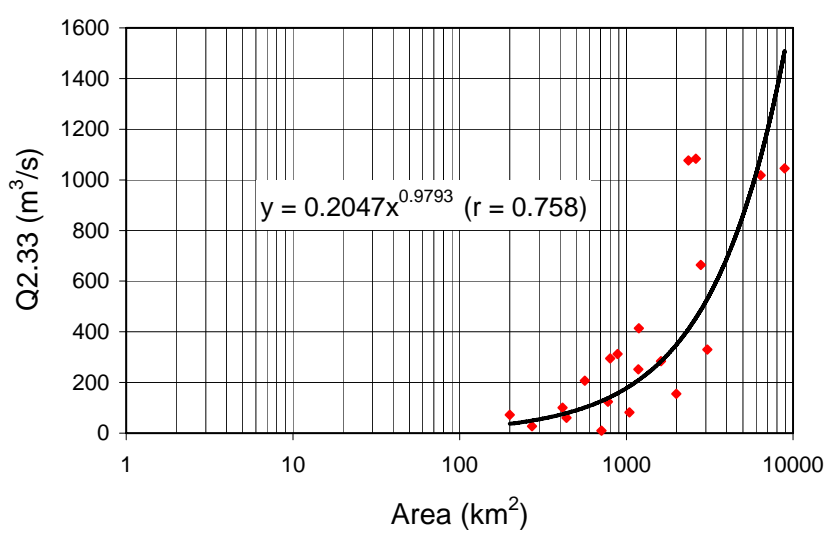

Fig. 5. Regional relationship of average flood peak discharge in down stream catchments of Karun.

sults of index flood method were also applied in determination of convenient duration of rainfall. Rainfall was initially analyzed for duration of 1,2 and 3 days as shown in Fig. 11 for 1 day duration and then 1-day duration was selected based on comparing RR model results and flood index hydrographs in gage stations for different retune periods. A sample of the flood frequency hydrographs shown in Fig. 12 for Dez dam.

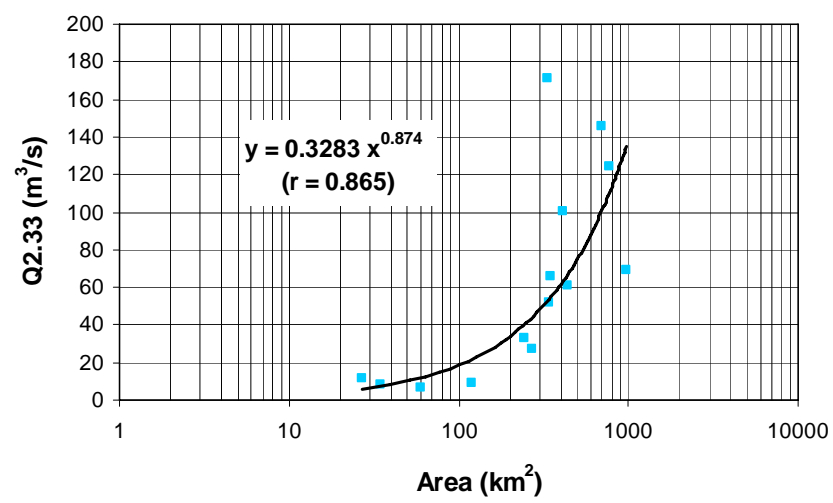

Fig. 6. Regional relationship of average flood peak discharge in down stream catchments of Dez.

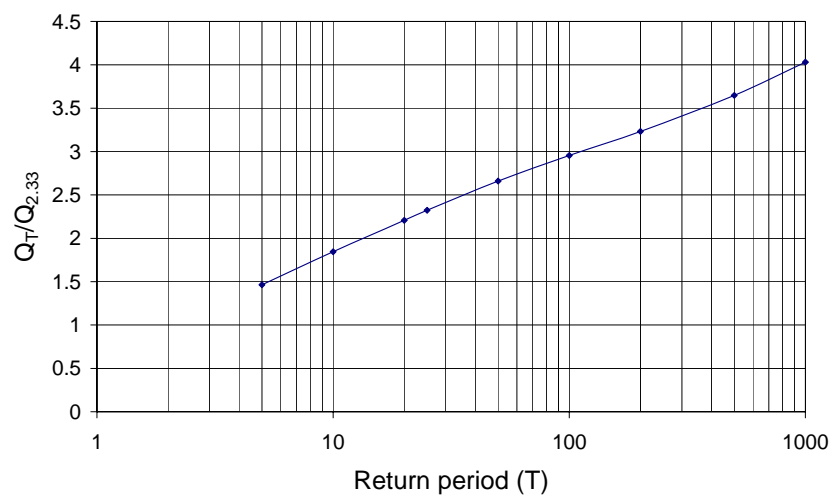

Fig. 7. Relationship of $Q_{T} / Q_{2.33}-T$ for Karun catchment.

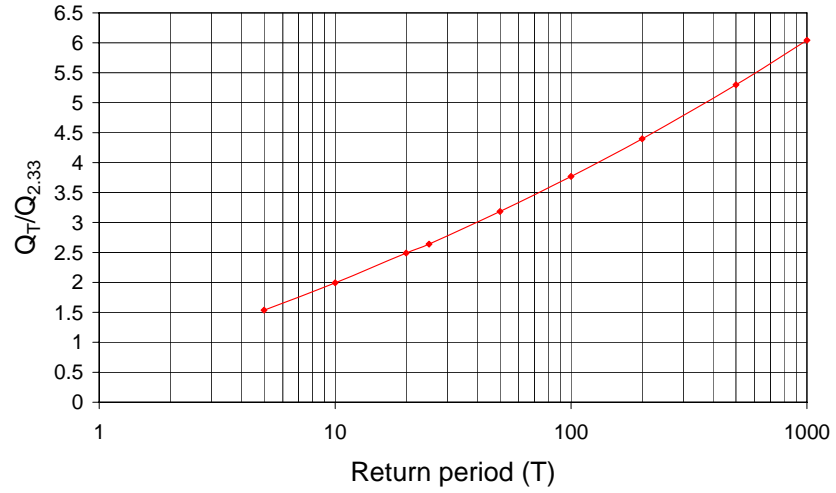

Fig. 8. Relationship of $Q_{T} / Q_{2.33}-T$ for Dez catchment.

\subsection{Reservoirs attenuation}

The upper catchments configuration for flood mitigation plans in floodplains areas has been considered 2010 time horizon in which Karun IV, and Upper Gotvand dams would be operated. Consequently, ignoring one existing runoff river hydropower dam, a 5 big reservoir system, including Karun IV, Karun III, Karun I and Upper Gotvand dams at 


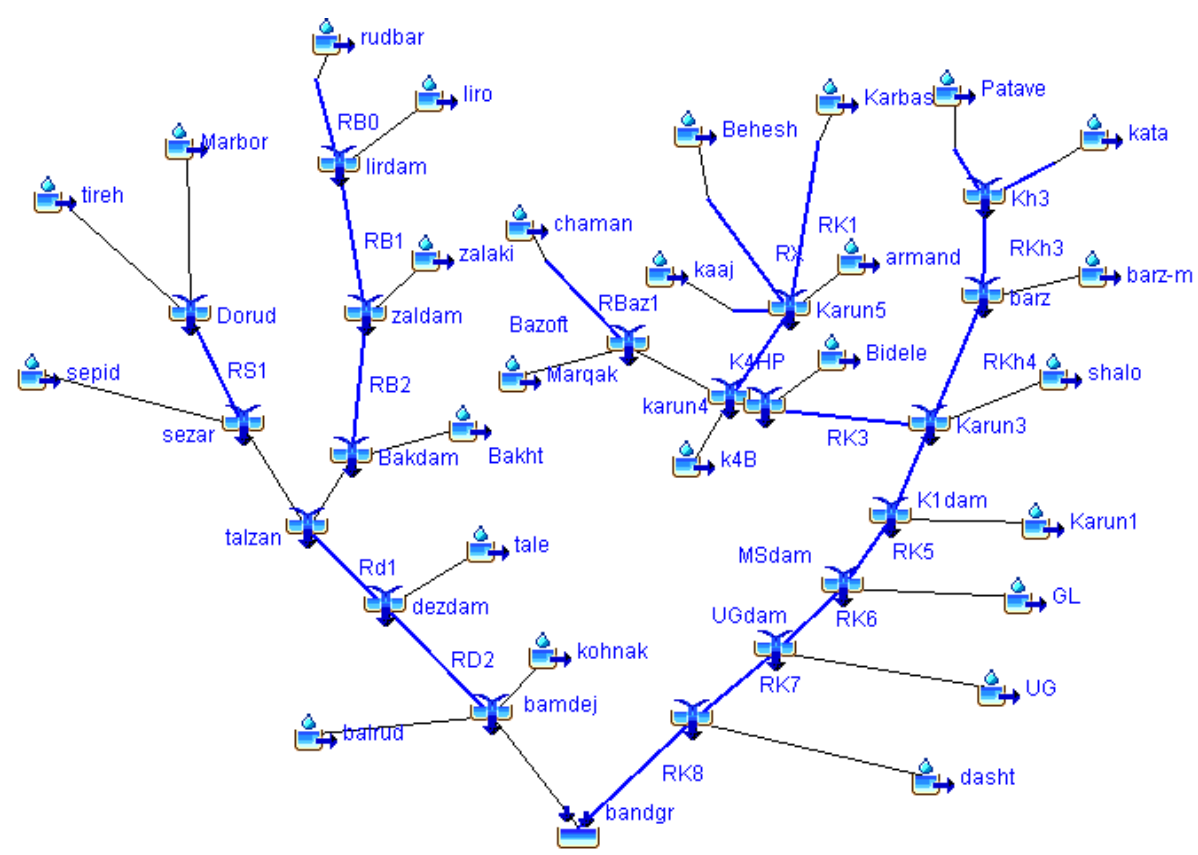

Fig. 9. Layout of Dez and Karun reservoir system in 2010.
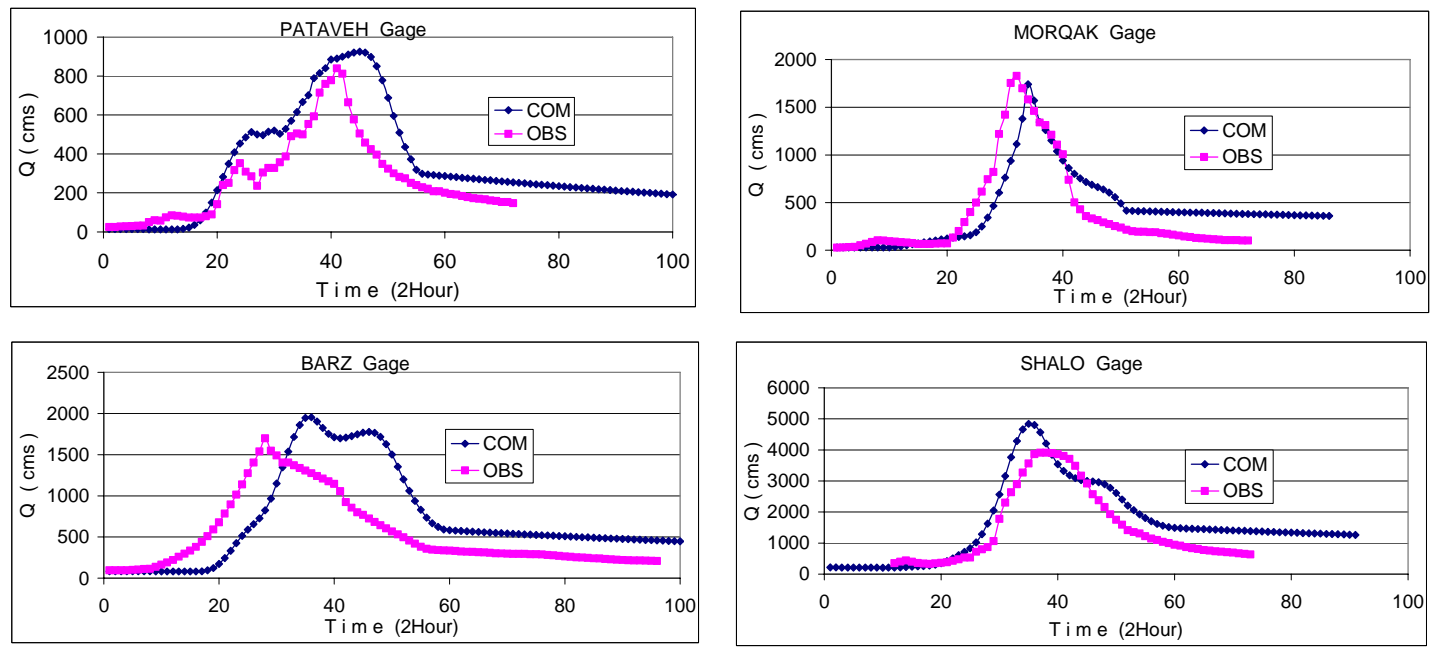

Fig. 10. Generating elevation points between two cross sections in river bed.

the Karun catchment and Dez dam at the Dez catchment has been considered in the design of downstream flood mitigation plans. Dez and Karun reservoirs system in full development horizon shown in Fig. 13. Under operation and construction scheme has been considered in estimating flood magnitude of down stream area.

In the Karun river, the peak discharges at the outlet of Karun catchment after superposition of intermediate catchments hydrograph are 3495 and $10010 \mathrm{~m}^{3} / \mathrm{s}$ for the 5 and 1000 year return periods, respectively. In the Dez river, disregarding to flood attenuation in floodplain area, peak dis- charge magnitude are 4337 and $9169 \mathrm{~m}^{3} / \mathrm{s}$ for the 5 year and 1000 year return periods respectively after confluence of tributaries. The results of this section are flood magnitude and hydrograph in entrance of flood plain area for different return period (discharge - probability curve).

\subsection{River routing}

Hydrodynamic (HD) modeling of the river is necessary in order to determine floodplain discharge, water level and inundation areas in two condition of without and with miti- 


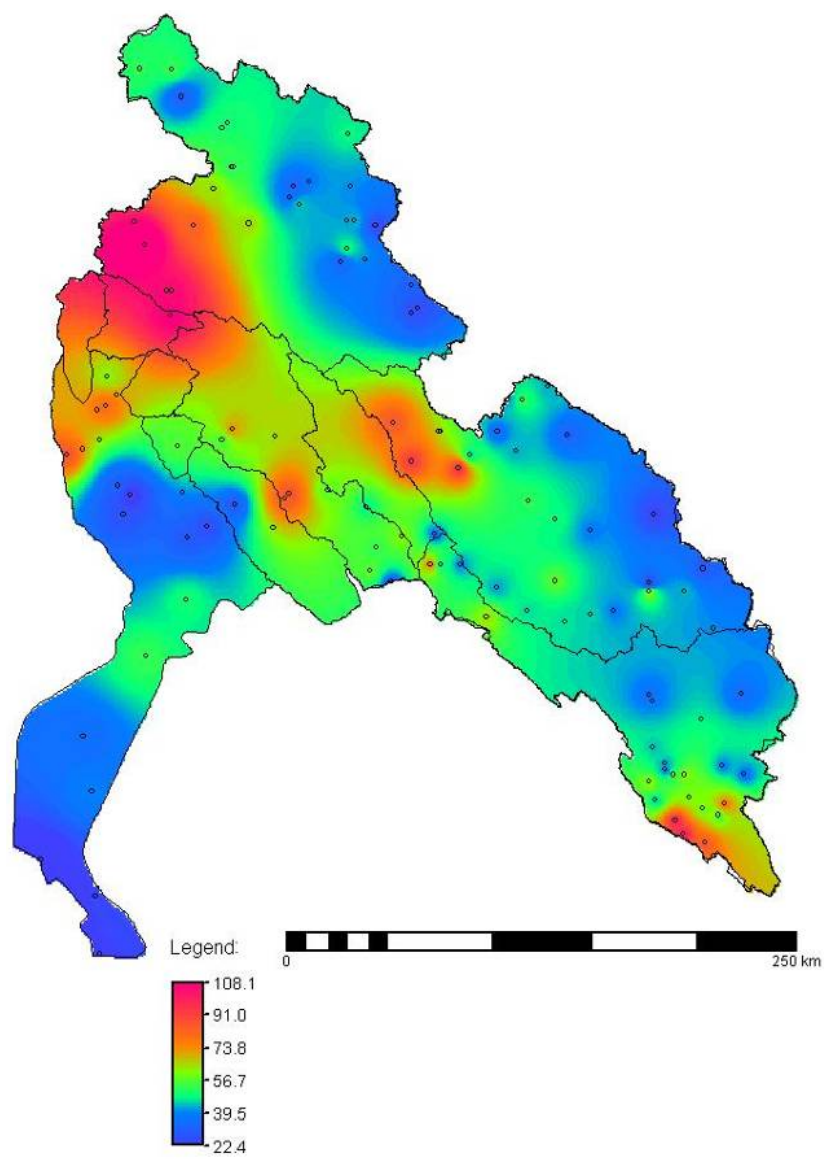

Fig. 11. The merged DEM of the region and extending of the cross section.

gation plan. For this purpose, one dimensional models of MIKE 11-HD and HEC-RAS were examined in steady and unsteady and the result was the same for the same input data. Geographical data was processed based on existing 820 cross section of river bed and 1:25000 topographic maps of floodplain areas. In HEC-RAS model, unsteady flow equations are solved in the main river and flood way. One dimensional Sain-Venant equations have been modified for these two flow path. In order to solve the modified equations, implicit finite differences method is applied incorporating with Newton Raphson approach. Four points scheme called Box scheme is used in this approach.

In order to cover two dimensional aspect of flood inundation in flood plain areas, following procedure was applied in HD model:

1. Digital Elevation Model (DEM) of the region was built in GIS based on 1:25000 topographic maps.

2. DEM of river bed was build based on cross section data. A holistic method as shown in Fig. 14 was used to generate elevation point between two adjacent cross sections. Elevation points were produced by interpolation

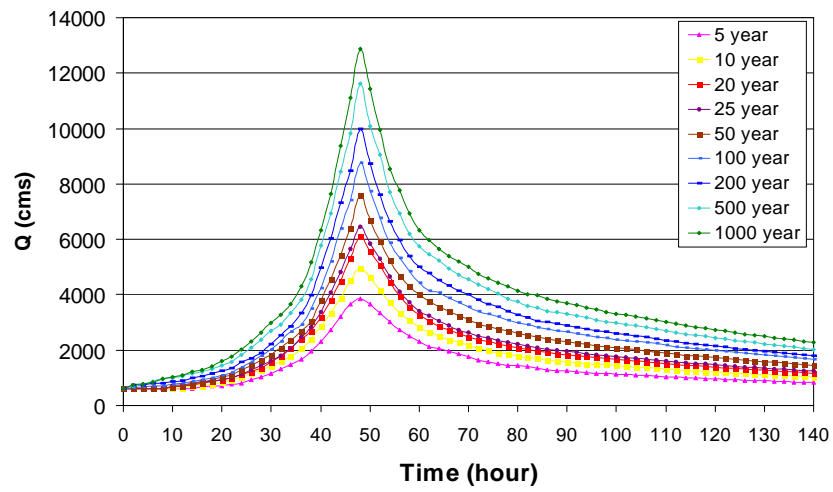

Fig. 12. Hydrographs for different return periods at Dez dam.

method and then DEM of river bed was build based on the elevation points.

3. DEMs of region and river bed was merged in one model. Figure 15 shows a part of merged DEM of river bed and floodplain areas. This model has been applied not only in extending the river cross sections to flood way but also in determination of inundated areas based on the HD model results.

4. An application tool was developed in Arcview to extend river bed cross section to floodplain areas.

5. Encroachments were determined by try and error method in different return period and certain flood mitigation plan to define real flood plain areas according to initial results of water surface and the feature of cross section. Figure 16 shows an example of cross section in case of improving/not improving of encroachments in the floodplain area.

Calibration of HD model was carried out in two case of steady and unsteady flow based on the observed rating curves and hydrographs. The results of calibration for steady state circumstance shown in Fig. 17. In addition steady state calibration, calibration in unsteady circumstance was carried out for simulation existing natural diversion. Satellite image of natural diversion in Dez river shown in Fig. 18. A function has been obtained for diverted flow based on observed hydrographs and HD results as shown in Fig. 19.

Flood hydrographs were routed along the rivers in HD model to determine discharge - probability curve in addition to discharge - stage curve in downstream river reaches. In order to determine inundated areas, the results of the hydraulic model converted to GIS format by HEC-GeoRAS extension in the mergedDEM of region. The inundation area and depth was computed by using TIN model and processing the hydraulic data including water levels and surface cross section width. 


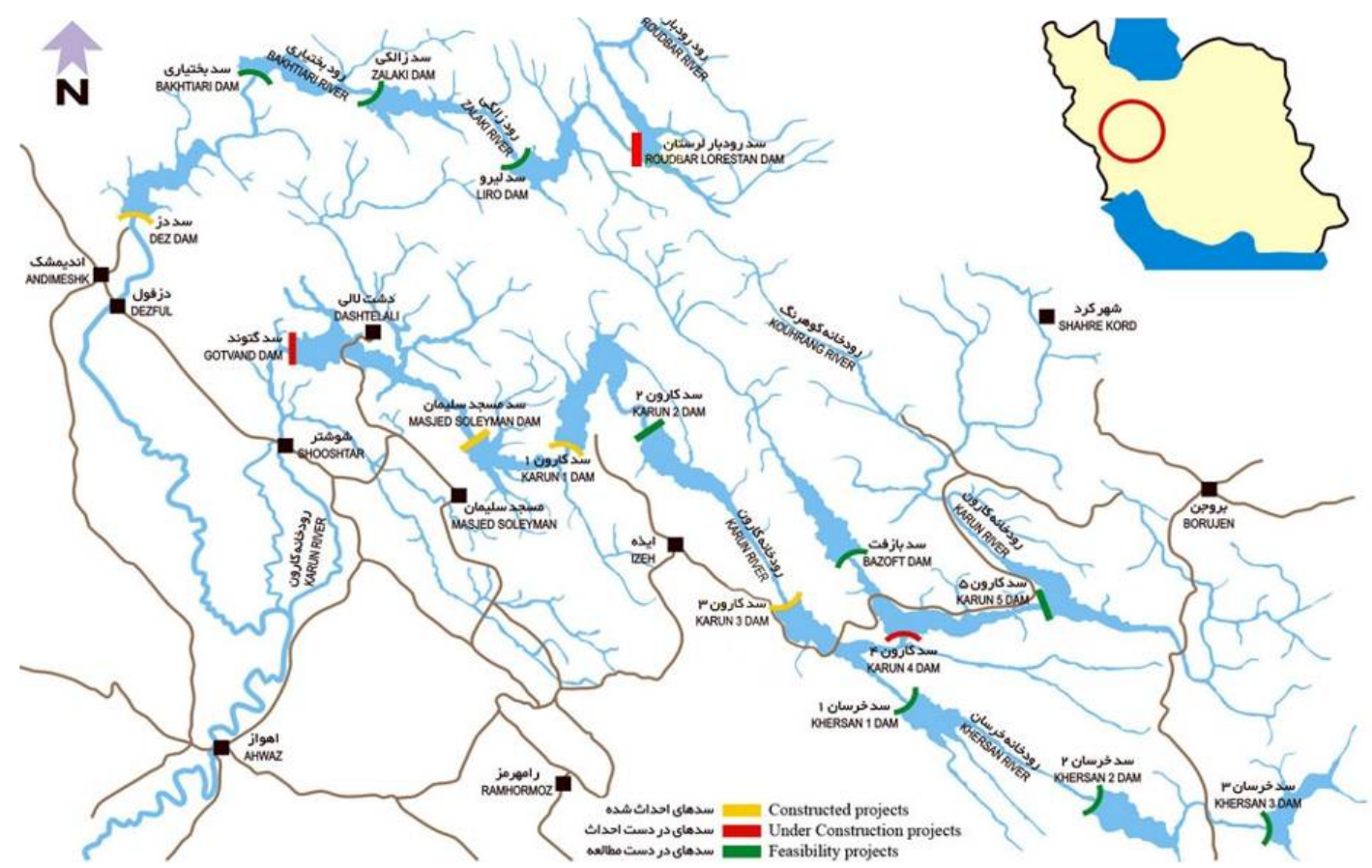

Fig. 13. Layout of Dez and Karun reservoir system in full development horizon.

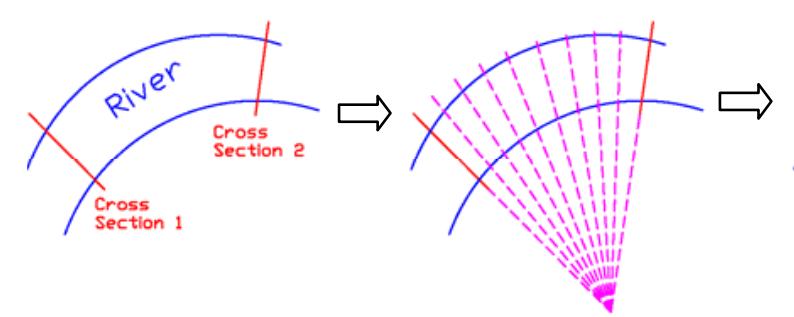

1-Existing Condition

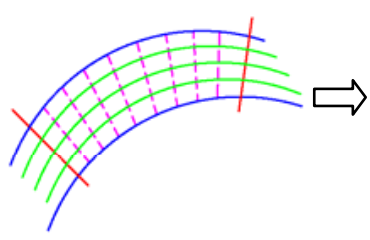

3-Generating Parallel Lines

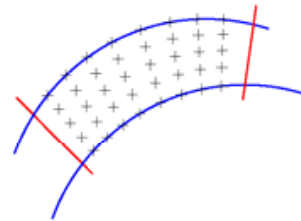

4-Generating Points

Fig. 14. Generating elevation points between two cross sections in river bed.
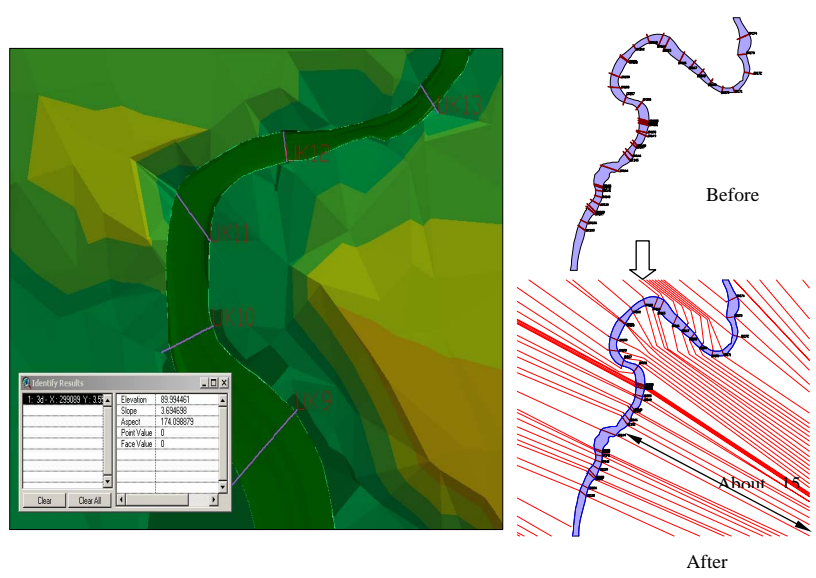

Fig. 15. The merged DEM of the region and extending of the cross section.

\subsection{Flood mitigation plans}

\subsubsection{Detention dam}

In the future feature of Dez and Karun river system, only intermediate catchments in downstream of the Upper Gotvand (UG) dam will remain without flood control facilities. Therefore, one of the main sources of flood in the area is the Shoor River at down stream of UG, where detention dams have been considered as an effective mitigation plan in this catchment. A detention dam can reduce the flood discharge and change probability - discharge function as Fig. 20a.

\subsubsection{Dyke and levee}

Levees can prevent flood spreading in the vulnerable reaches and consequently reduces damage up to zero for the floods which less than the design flood magnitude. By constructing this measure, the cross section of flood way will be confined 

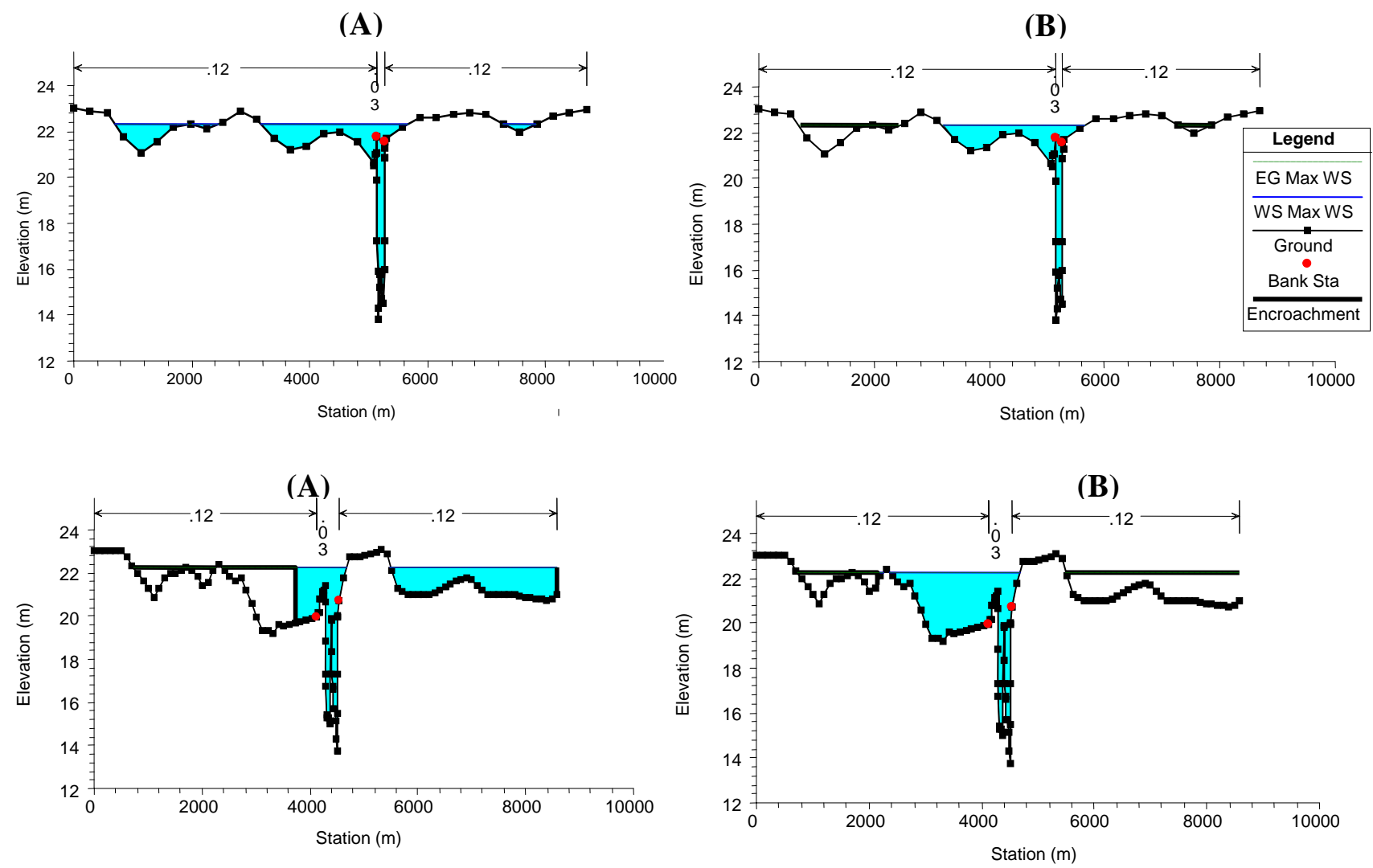

Fig. 16. A sample of cross section for (a) not improved and (b) improved floodplain encroachments.

and therefore river storage capacity will be decreased in the confined reaches of river. This is the main factor cause to investigate whole river reaches according to flood damagereduction by structural measures. Dykes reduce the damage by reducing the flood damage in a certain stage and discharge. This is achieved by prevention of flood overtopping, hence the stage-damage function are modified as Fig. $20 \mathrm{~b}$.

Figure 21 shows the location of proposed detention dam sites 1 and 2, located on the tributary and the main river of Shoor basin, respectively. Proposed alternatives of dyke construction in Dez and Karun rivers were considered in four reaches according to the "damage areas" as shown in Fig. 22.

\subsubsection{Flood diversion}

Flood can be diverted from the river reach with high damages and returned to the reach in high-capacity or low-damages. Same as the detention dam (Fig. 20a), flood peak discharge is reduced in the river immediately after diversion point. Natural diversions into the floodways currently reduce flood damage in the existing situation of Dez and Karun river system.

Different alternatives of flood diversion into existing estuaries have been proposed in the Big Karun. Figure 23 shows the alternatives of flood diversion from Big Karun into the estuaries.
Table 2. Duration of flood staying inside the residential units.

\begin{tabular}{lll}
\hline Days & Frequency $(\%)$ & $\begin{array}{l}\text { Cumulative } \\
\text { frequency }(\%)\end{array}$ \\
\hline Less than $12 \mathrm{~h}$ & 9.3 & 9.3 \\
12 h up to 1 day & 16.7 & 25.9 \\
$2-3$ & 5.6 & 31.5 \\
$4-6$ & 11.1 & 42.6 \\
$7-10$ & 33.3 & 75.9 \\
$>11$ & 24.1 & 100.0 \\
\hline
\end{tabular}

\subsubsection{Flood damage estimation}

In order to assess each alternative of mitigation plans, it needs to estimate damage reduction along the whole rivers in comparison to without project situation. For this purpose, inundation areas were computed incorporating with inundation depths for different mitigation plan, flood return periods and damage properties separately. Potential damage of each property has been estimated by surveying in the region and identifying the activities. There is no human live loss in the region during historical flood events because of very slow rising and recession of flood as well as traditional flood warning system. 

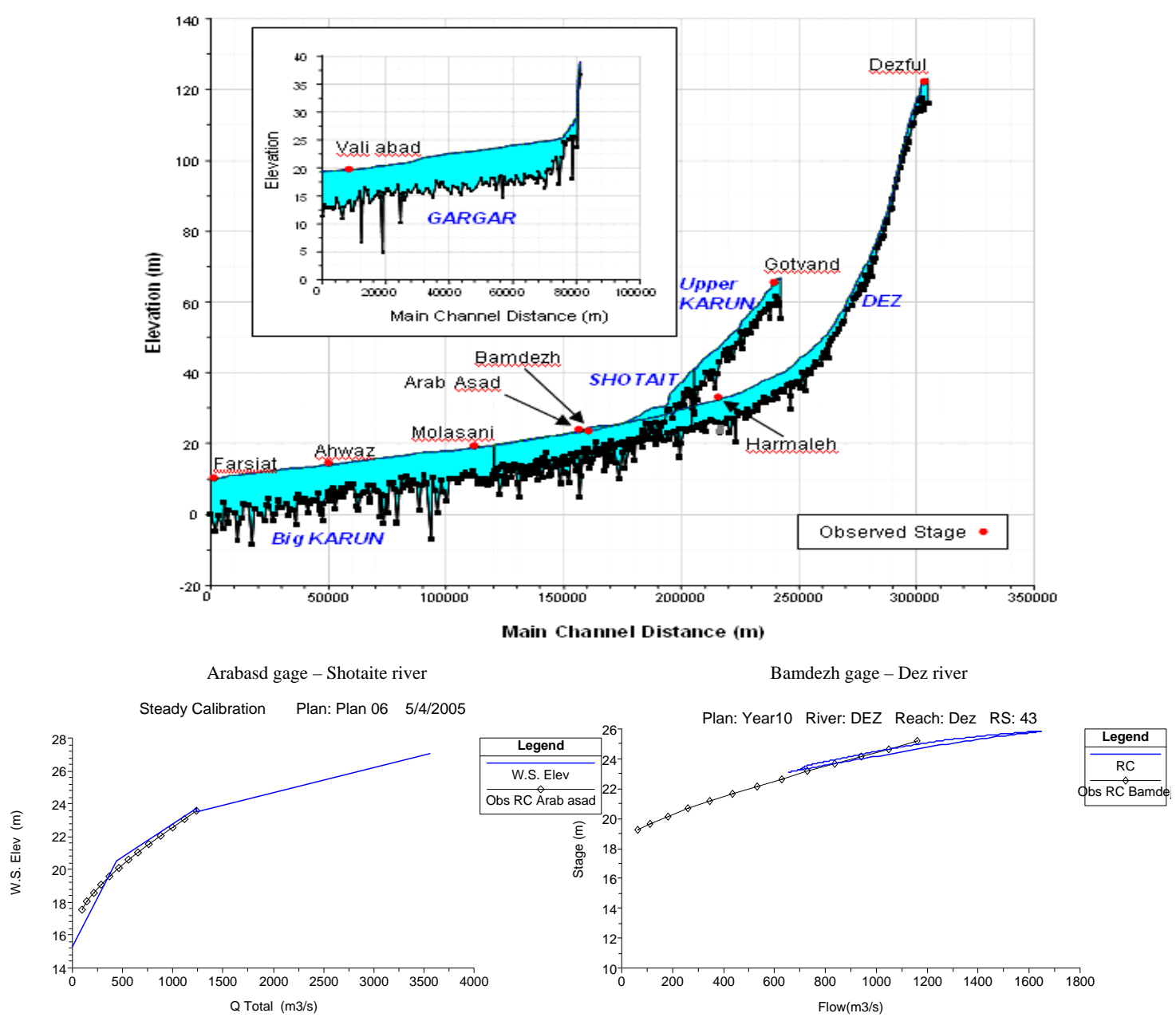

Fig. 17. Steady state calibration results of HD model.

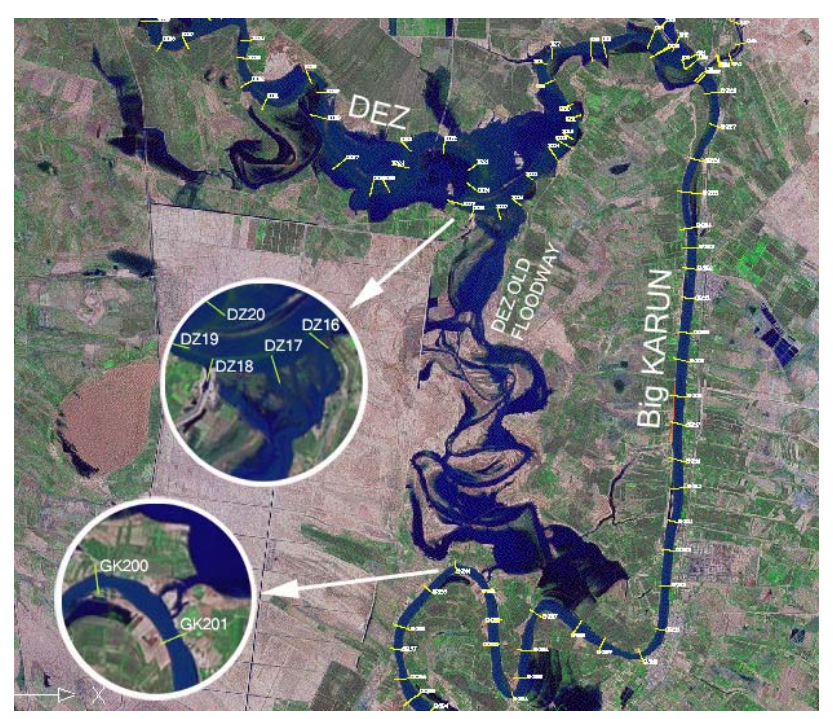

Fig. 18. Existing natural diversion of Dez River to Big Karun (flood of Mar 1995).
The main occupation and activity of the residents as shown in Fig. 24, consists 39.5\% agriculture, 5.8\% animal husbandry, $25.6 \%$ agriculture and animal husbandry, $2.3 \%$ simple labour and the remainder were involved in other activities or a combination of them. Residential units have been built by using materials such as brick, cement blocks and mud and most of them are single floor without any basement. Figure 25 shows the type of construction materials for residential units. Flood duration in residential unit shown in Table 2 based on historical flood events. There is no clear source about flood damage and relative costs on residential units in historical extreme floods. However, each residential unit bears 100 to 1000 US\$ after flood inundating according to the properties as shown in Fig. 26. The damage rate in agricultural and farm areas is up to $100 \%$ of value of production regarding to flood depth. Based on home appliances and properties, there is no damage in most flood condition. According to the survey information about $29 \%$ and $26 \%$ of people use insurance service for residential units and agricultural crops, respectively. However, the rate of damage compensation by insurance companies has 


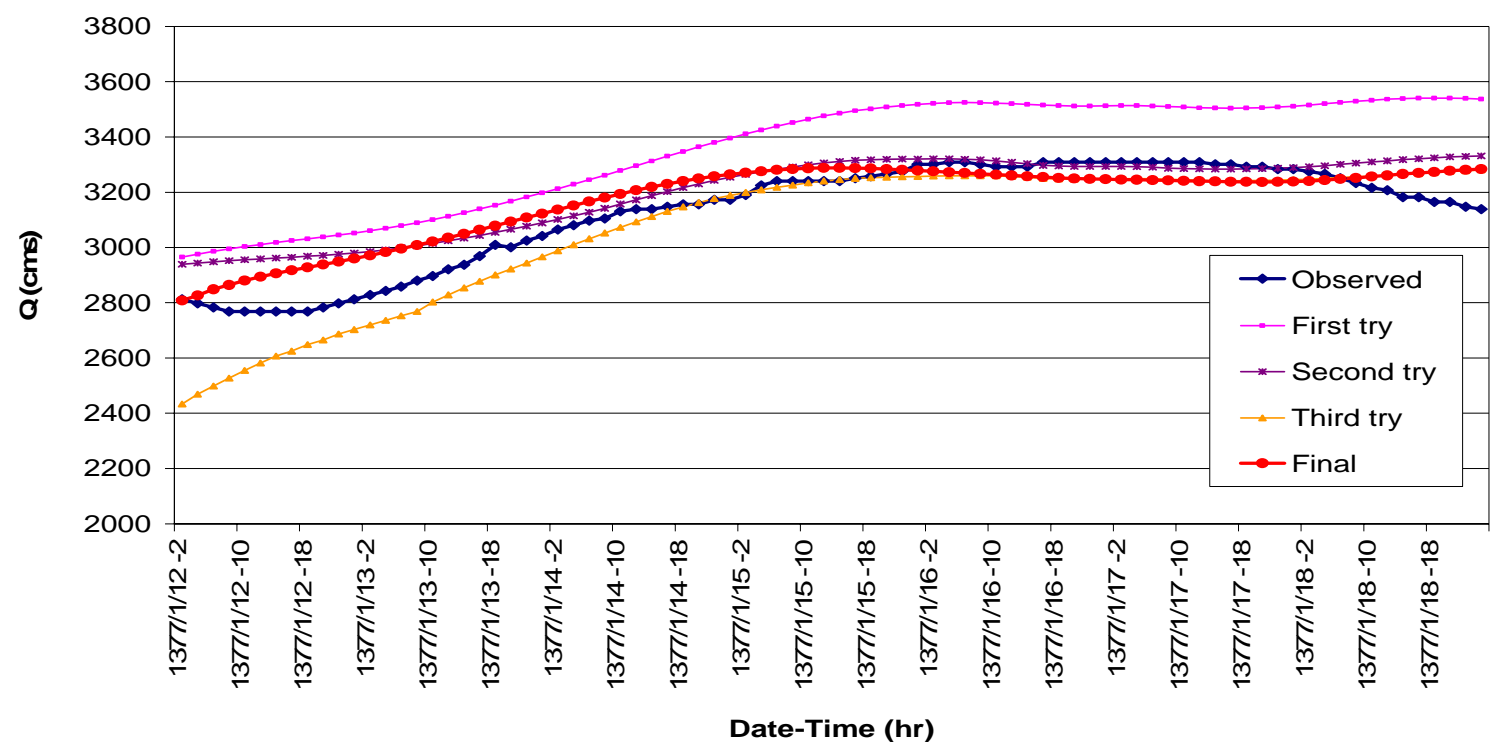

Fig. 19. Observed and HD model's hydrographs in downstream of natural flood way.

Table 3. Expected Value (EV) of damage reduction (FDA results) in flood mitigation alternatives (mUS\$).

\begin{tabular}{|c|c|c|c|c|c|c|c|c|c|c|}
\hline \multicolumn{4}{|c|}{ Detention dam } & \multicolumn{4}{|c|}{ Levees } & \multicolumn{3}{|c|}{ Flood diversion } \\
\hline Situation & & $\begin{array}{l}\text { Annual } \\
\text { EV of } \\
\text { damage }\end{array}$ & $\begin{array}{l}\text { Annual } \\
\text { EV of } \\
\text { damage } \\
\text { reduction }\end{array}$ & Situation & & $\begin{array}{l}\text { Annual } \\
\text { EV of } \\
\text { damage }\end{array}$ & $\begin{array}{r}\text { Annual } \\
\text { EV of } \\
\text { damage } \\
\text { reduction }\end{array}$ & Situation & $\begin{array}{l}\text { Annual } \\
\text { EV of } \\
\text { damage }\end{array}$ & $\begin{array}{l}\text { Annual } \\
\text { EV of } \\
\text { damage } \\
\text { reduction }\end{array}$ \\
\hline $\begin{array}{l}\text { Without } \\
\text { project }\end{array}$ & & 7.74 & 0 & $\begin{array}{l}\text { Without } \\
\text { project }\end{array}$ & & 14.5 & 0 & $\begin{array}{l}\text { Without } \\
\text { project }\end{array}$ & 14.49 & 0 \\
\hline $\begin{array}{l}\text { With } \\
\text { project }\end{array}$ & $\begin{array}{l}\text { Dam } 1 \\
\text { Dam } 2 \\
\text { Two dam } \\
\text { system }\end{array}$ & $\begin{array}{l}1.1 \\
1.8 \\
5.8\end{array}$ & $\begin{array}{l}6.64 \\
5.9 \\
1.9\end{array}$ & $\begin{array}{l}\text { With } \\
\text { project }\end{array}$ & $\begin{array}{l}\text { GarGar reach } \\
\text { Bamdej reach } \\
\text { Ahwaz city } \\
\text { Farsiat region }\end{array}$ & $\begin{array}{l}15.4 \\
14.15 \\
14.1 \\
13.79\end{array}$ & $\begin{array}{r}-0.93 \\
0.35 \\
0.39 \\
0.71\end{array}$ & $\begin{array}{l}\text { With } \\
\text { project }\end{array}$ & 12.1 & 2.4 \\
\hline
\end{tabular}

Table 4. Economic evaluation results for mitigation alternatives (rate of retune 10\%).

\begin{tabular}{|c|c|c|c|c|c|c|c|}
\hline \multirow{2}{*}{$\begin{array}{l}\text { Mitigation } \\
\text { alternative }\end{array}$} & \multicolumn{3}{|c|}{ Detention dam } & \multicolumn{3}{|c|}{ Levee } & \multirow[t]{2}{*}{ Flood diversion } \\
\hline & $\begin{array}{r}\text { Sing } \\
\text { Dam } 1\end{array}$ & $\begin{array}{l}\text { dam } \\
\text { Dam } 2\end{array}$ & $\begin{array}{l}\text { Two } \\
\text { dam }\end{array}$ & $\begin{array}{r}\text { Bamdej } \\
\text { area }\end{array}$ & $\begin{array}{r}\text { Ahwaz } \\
\text { city }\end{array}$ & $\begin{array}{r}\text { Farsiat } \\
\text { area }\end{array}$ & \\
\hline $\mathrm{B} / \mathrm{C}^{*}$ & 0.78 & 1.34 & 0.7 & 0.29 & 1.03 & 0.84 & 1.1 \\
\hline $\mathrm{NPV}^{*}(\mathrm{mUS} \$)$ & -3 & 4.42 & -8 & -8.3 & 0.1 & -1.29 & 1.37 \\
\hline $\operatorname{IRR}^{*}(\%)$ & 7.9 & 12.9 & 7.1 & 1.6 & 10.3 & 8.4 & 10.6 \\
\hline
\end{tabular}

* B/C: Benefit cost ratio, NPV: Net Present Value, IRR: Internal Rate of Return. 


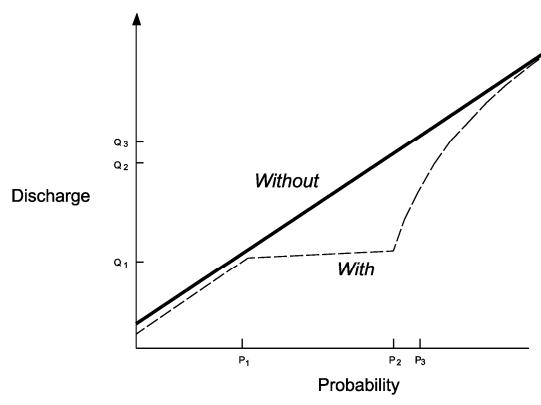

a) Detention and Diversion

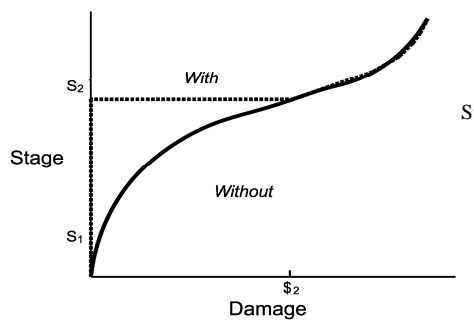

(b) Levees and Dykes

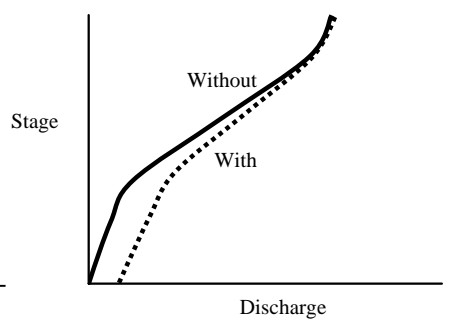

c) River Bed improvement

Fig. 20. Modification of probability - discharge-stage functions by mitigation plans.
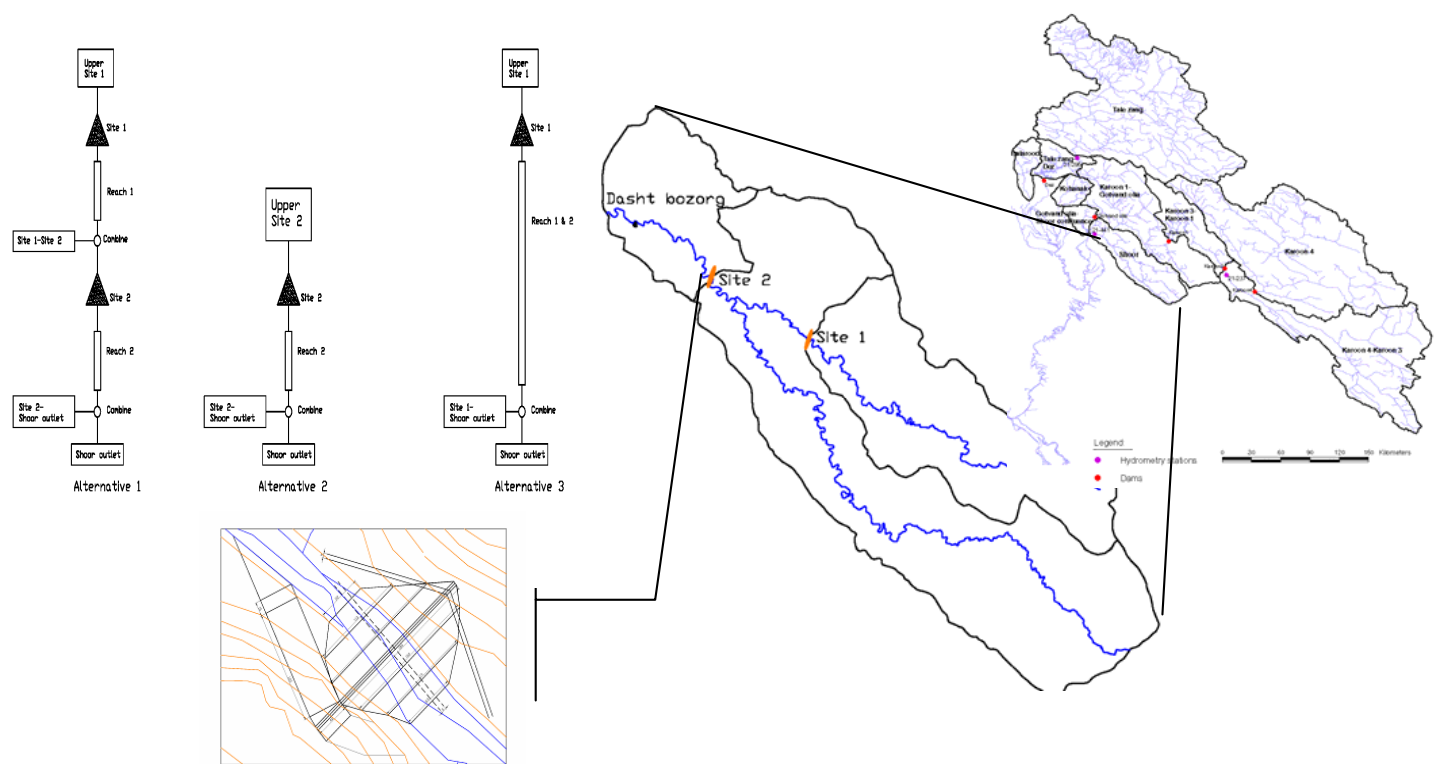

Fig. 21. Location and layout of detention dams in Karun river basin.

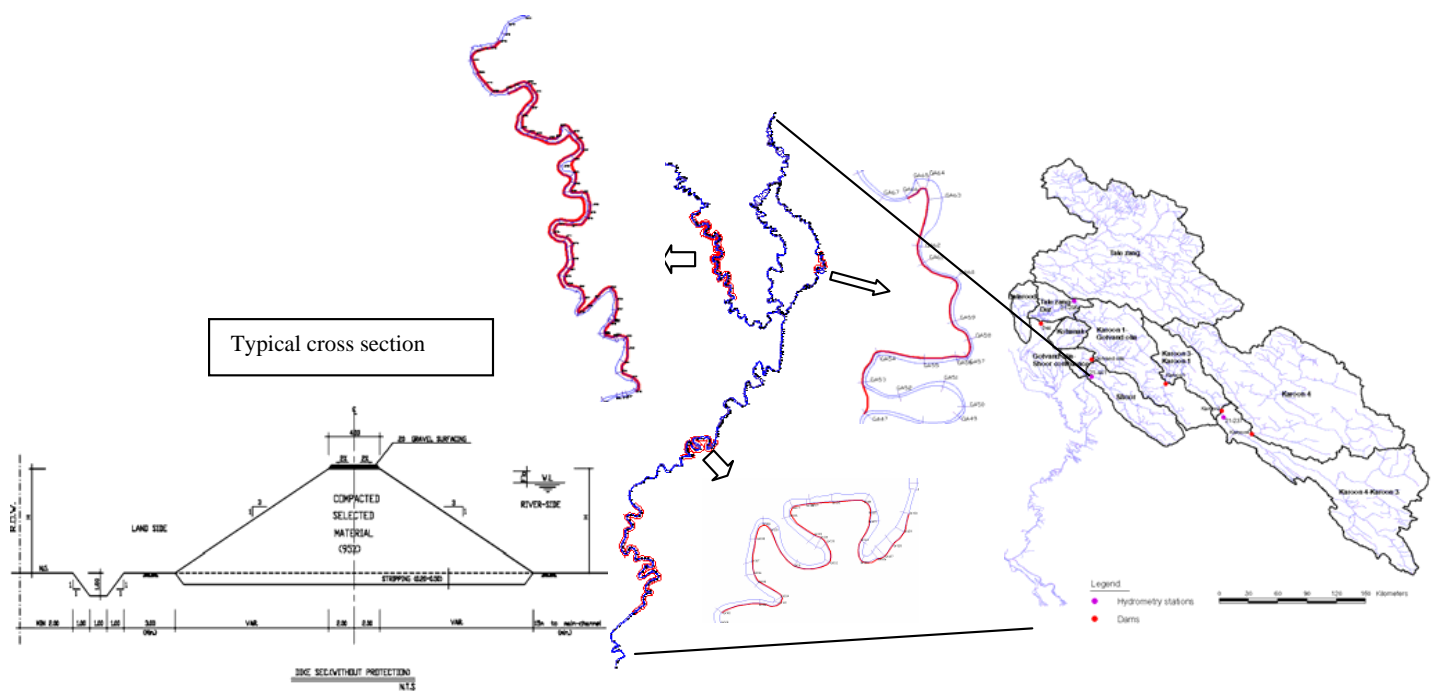

Fig. 22. The location of proposed levees in Dez and Karun rivers. 

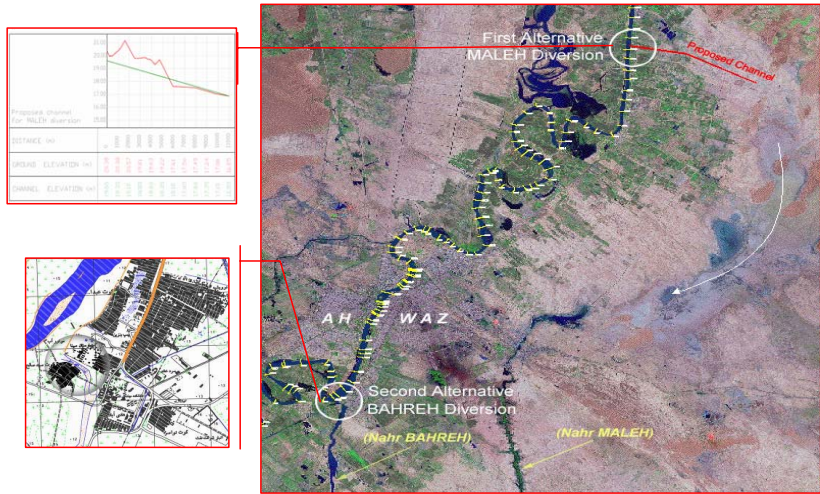

Fig. 23. Ahwaz city location and flood diversion alternatives.

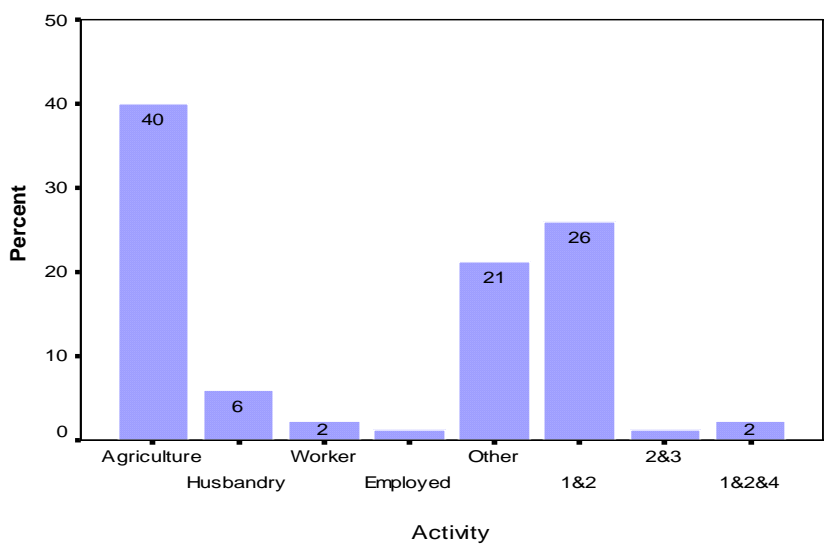

Fig. 24. Percentage of main activities in the flood plain area.

been zero for residential units and ignorable for agricultural units. The applied flood fighting methods which used by native people shown in Fig. 27.

Figure 28 shows villages intensity, agricultural areas, fish cultivation and flood inundation area as well as overlaying the layer to estimate potential damage in each magnitude of flood and certain plan. The potential damages in two cases of with/without project have been estimated for all scenarios of flood mitigation plan in returns period of 5 to 200 years. Higher return period which has very low occurrence probability, has been ignored in estimation of expected value of damages due to ignorable integration of damage-probability function (Eq. 2).

HEC-FDA was used to estimate expected value of damage reduction according to without/with project situation in whole reaches of the river. Flood frequency curve, rating curve and potential flood damage in different reaches are the input of the model and damage - probability curve incorporation with expected value of damage reduction in each reaches are output of the model. The results HEC-FDA model shown in Table 3 for different scenarios of mitigation plan.

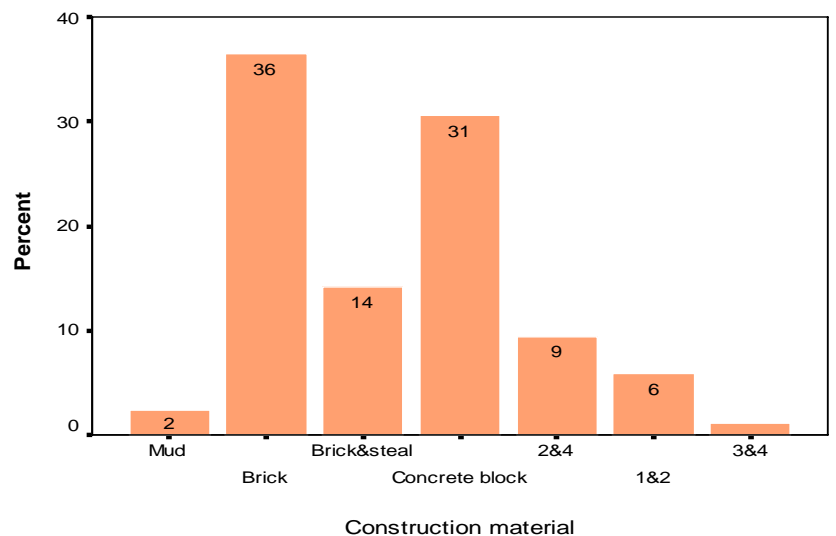

Fig. 25. Typical applied materials in residential units.

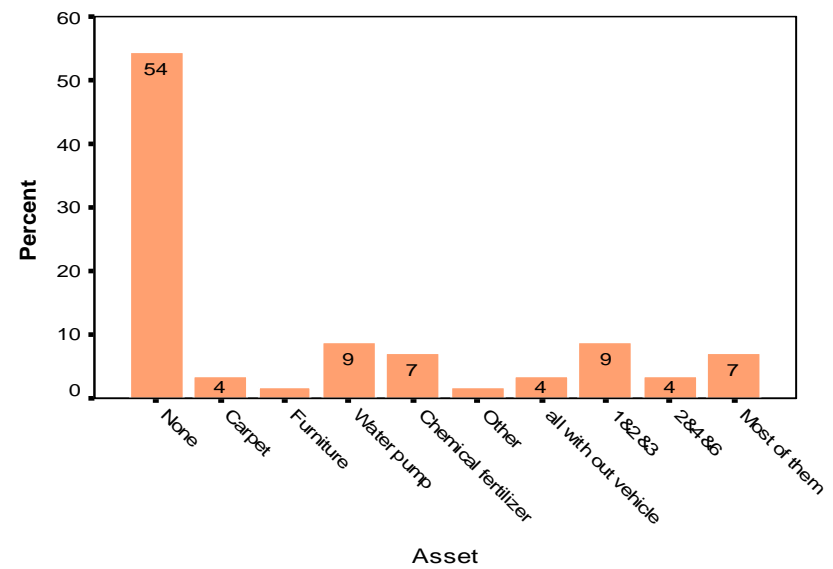

Fig. 26. Flood damage percentage to home appliances and properties.

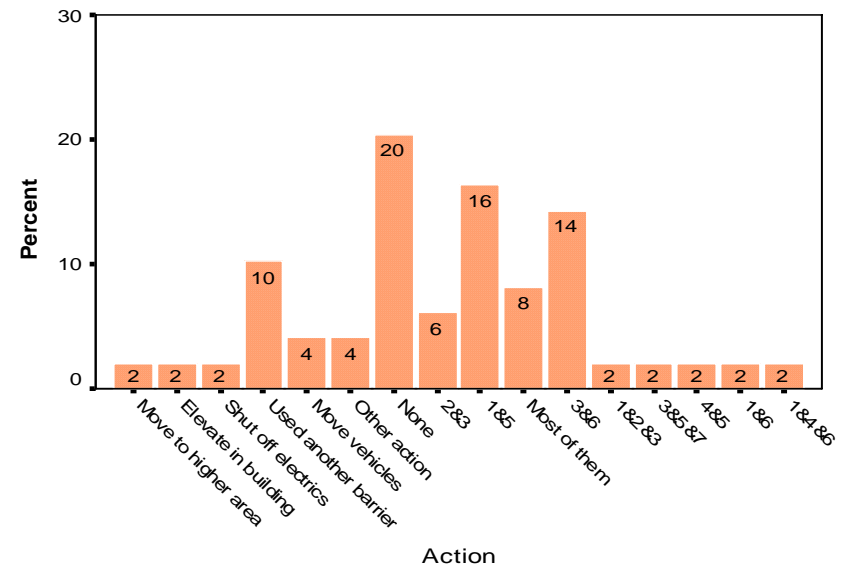

Fig. 27. Conventional flood fighting methods in the region.

\subsection{Economic assessment}

Economical analysis consists cost/benefit analysis of various flood mitigation alternative after estimation of capital, operational and maintenance costs as total costs of mitigation plan and damage reduction as annual benefits. In the analysis, 

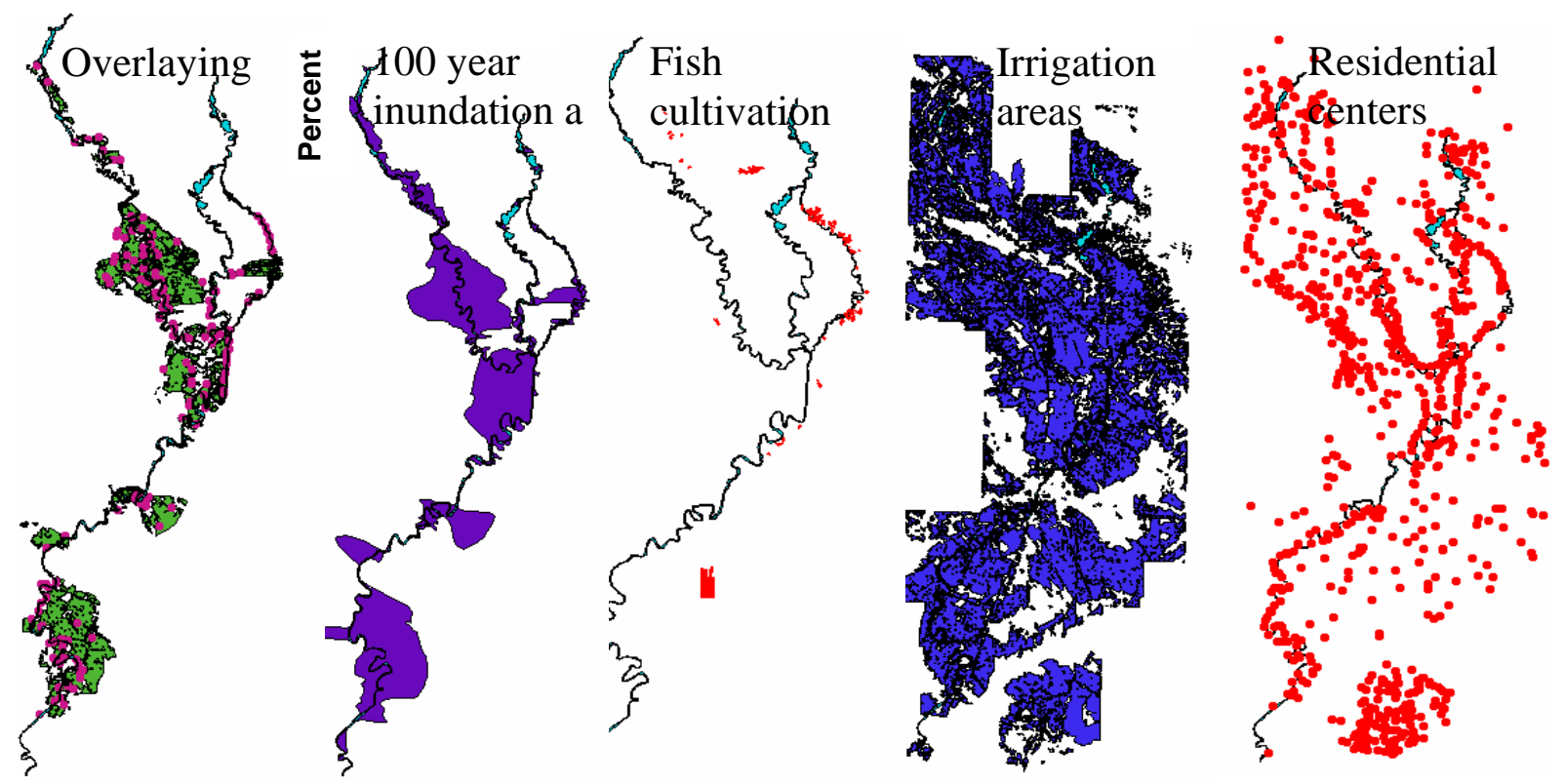

Fig. 28. Location of properties and overlaying the layers of data in potential damage estimation.

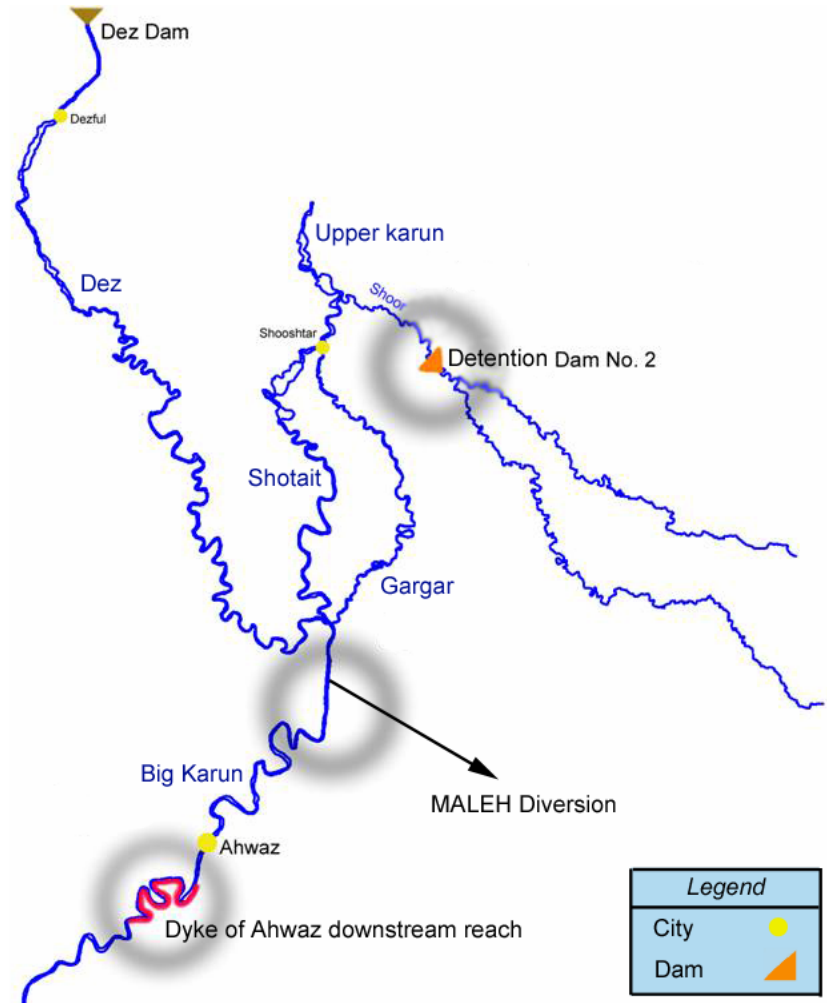

Fig. 29. Flood mitigation master plan of Dez and Krun rivers floodplain. benefit cost ratio (B/C), net present value of benefits (NPV), internal rate of return (IRR) has been calculated with considering annual interest rate $(i)$, cash flow of construction period and operation costs and benefits. The internal rate of return is the interest rate received for an investment cost and benefits that occur at regular periods. It means that internal rate of return is certain $i$ in which total present costs and benefits are equal. Economic evaluation results shown in Table 4 for the mitigation alternatives.

The results reveal that:

1. In detention dam alternatives, single dam configuration of dam site (1) and two dams configuration are not justifiable according to economic indexes of Table 4. The benefit/cost ratio and NPV of single dam system of dam site (Eq. 2) are more than justification threshold based on the region interest. The IRR of this plan is about $13 \%$ which is a convenient rate in the infrastructural development.

2. In the levees alternatives, by constructing the proposed dykes in the inundation reach of Gargar river, damage would increase in comparison with "without project" condition. So, this alternative was rejected even without presenting economical indexes. The proposed dyke in Bamdezh reach in Dez River was not justifiable according the low economic indexes. The dyke plan in downstream of Ahwaz city in Big Karun river with benefit/cost ratio more than 1 (for $i=10 \%$ ) and IRR of $10.26 \%$ (more than $10 \%$ ) would be justifiable economically. The dyke in Farsiaat downstream had benefit/cost ratio less than 1 (for $i=10 \%$ ). IRR of this plan is $8.4 \%$ and was rejected economically. 
The benefit/cost ratio of diversion plan was more than 1 in rate of return of $10 \%$. The IRR of this alternative was $10.64 \%$ (more than 10\%), therefore it was economically accepted.

\section{Conclusions}

This paper is mainly presenting a master plan for damagereduction in the floodplain areas of Dez Karun rivers. Although, improving the management of reservoirs flood control particularly in the upper catchments can be carried out as a non-structural approach of flood mitigation, but it needs the online monitoring system for real time flood control which is not available now.

As a first step of analysis, flood magnitude was determined in the damage areas after reservoirs flood peak discharge attenuation and combining intermediate and downstream subcatchments flood hydrographs. The next step was hydrodynamic analysis of the river in which digital elevation model (DEM) of the river and the floodplain areas was built by merging more than 800 cross sections data and topographic maps. Hydraulic model of the river was developed after extending the cross sections, defining the floodway area in each cross section and calibrating the model in steady and unsteady flow condition. Inundation areas and depths were determined for different return periods in "without project" and "with project" condition by using the hydraulic and DEM.

In order to estimate potential flood damages of the region, a set of questionnaires were designed and filled up in critical areas. The results of this field survey were used in determination of damage magnitude for different inundation depths in different properties. The layers of inundation area and depth and potential damages were overlaid and then damage amount of inundated area was determined for different floods in with/without project condition for different mitigation alternatives separately.

The mitigation plans including detention dams, Levees and dykes and flood diversions were investigated considering the impact on whole rivers reaches. In order to identify the benefits of flood mitigation plans, flood damage analysis was carried out by HEC-FDA model. In the next step, the expected value of annual damage and damage-reduction were determined for the alternatives and economical indexes of each plan were evaluated.

Optimum feature of flood mitigation plan contained 1) a detention dam on Shoor river (tributary in downstream of the Karun basin), 2) diversion channel from Big Karun from upstream of Ahwaz city to estuary, 3) Levees in downstream of Ahwaz city. Construction of diversion channel was essential due to safety of Ahwaz city and the existing risk of human lives despite of no report of human lives loss in the city. However the proposed measures in up stream of the city have high priority because of risk of human lives. Flood damage would be mostly reduced in Karun and Big Karun rivers rather than Dez river by implementing optimum mitigation plan. The proposed levees were not justifiable in the
Dez river reach because of negative impact on downstream. Other river training alternatives e.g. dredging the river bed in downstream of Dez dam could not be taken into account as a sustainable development plan because of releasing sediments from Dez reservoir. Therefore, the only possible alternative for flood mitigation in Dez river would be the reservoir flood control management in Dez dam. The study of enhancing height of Dez dam is already carrying out and it has been recommended to consider flood control purpose in this studies. By considering enforcement of Dez dam flood control rule as a only possible flood mitigation plan of Dez river, integrated flood mitigation plan of Dez and Karun rivers system would be as Fig. 29.

Acknowledgements. This paper has been prepared based on the Dez and Karun river system optimization project which carried out by Scot Wilson (UK) and Mahab Godss (Iran) companies collaboration. I appreciate experts in flood group specially Mahab Godss Co. experts who had remarkable contribution in this study.

Edited by: L. Ferraris

Reviewed by: two anonymous referees

\section{References}

Cheng, S. T., Yen, B. C., and Tang, W. H.: Stochastic risk modeling of dam overtopping, in: Reliability and Uncertainty Analyses in Hydraulic Design, edited by: Yen, B. C. and Tung, Y. K., ASCE, 123-132, 1993.

Flood Damage Reduction Analysis: HEC-FDA User's Manual, US Army Corps of Engineers Hydrologic Engineering Center, Davis, CA, 72 pp., 1998.

Tang, W. H. and Yen, B. C.: Probabilistic inspection scheduling for dams, in: Reliability and Uncertainty Analyses in Hydraulic Design, edited by: Yen, B. C. and Tung, Y. K., ASCE, New York, 107-122, 1993.

Tung, Y. K.: Risk-based design of flood defense systems, Flood Defense, Science Press, New York, 71-81, 2002.

Tung, Y. K. and Mays, L. W.: Risk and reliability model for levee design, Water Resour. Res., 17(4), 833-842, 1981a.

Tung, Y. K. and Mays, L. W.: Optimal risk-based design of flood levee systems, Water Resour. Res., 17(4), 843-852, 1981 b.

van Stokkom, H. T. C. and Smits, A. J. M.: Flood defense in the Netherlands: a new era, a new approach, Flood Defense, Science Press, New York, 34-47, 2002.

Vrijling, J. K.: Development in Probabilistic Design of Flood Defenses in the Netherlands, in: Reliability and Uncertainty Analyses in Hydraulic Design, edited by: Yen, B. C. and Tung, Y. K., ASCE, 133-178, 1993.

Yen, B. C. and Jun, B. H.: Risk consideration in design of storm drains, Proceedings, Third IAHR/IAWPRC International Conference on Urban Storm Drainage, Chalmers Univ. of Technology, Goteborg, Sweden, 2, 695-704, 1984. 